\title{
A note on the effect of food restriction on tissue ascorbic acid in guinea-pigs
}

\author{
By J. E. W. DAVIES AND R. E. HUGHES \\ University of Wales Institute of Science and Technology, Cardiff
}

(Received 15 April 1977 - Accepted 13 May 1977)

1. Male, adult guinea-pigs received a scorbutogenic diet and a daily supplement of $1.0 \mathrm{mg}$ ascorbic acid $/ 100 \mathrm{~g}$ body-weight.

2. Restriction of food intake for a period of $17 \mathrm{~d}$ resulted in a $25 \%$ loss in body-weight and a significant reduction in the retention of ascorbic acid by the spleen, liver and adrenal glands.

There is some evidence that the retention of ascorbic acid (AA) by tissues is related to the over-all metabolic activity of an animal. Differences in metabolic rate could explain the negative correlation of AA concentrations with age in both guinea-pigs and man and also the increase of tissue AA associated with protein-induced increases in growth rate (Andrews \& Brook, 1966; Brook \& Grimshaw, 1968; Hughes \& Jones, 1971; Williams \& Hughes, 1972). A reduction in metabolism resulting from a decreased intake of nutrient material might therefore be expected to induce a decrease in tissue AA concentrations. The experiment described in this note was designed to examine the effect of a reduction in food intake on the concentration of ascorbic acid in guinea-pig tissues.

\section{METHODS}

Two groups of eight adult male guinea-pigs (age, $120 \mathrm{~d}$ ) were used. Both groups received a scorbutogenic diet previously described (Williams \& Hughes, 1972). No AA was given for $7 \mathrm{~d}$; this depleted the tissues of AA and produced a satisfactory 'base line' (Hughes, Hurley \& Jones, 1971). On the eighth day, and daily until the end of the experiment, each animal received an oral dose of $1.0 \mathrm{mg} \mathrm{AA} / 100 \mathrm{~g}$ body-weight. Group A received unrestricted food. Group B received $10 \mathrm{~g}$ food/animal for days 8-16; this was reduced to $5 \mathrm{~g} / \mathrm{d}$ (days 16-19) and then to $3 \mathrm{~g} / \mathrm{d}$ (days 20-24), to produce a gradual but measurable weight loss. After $24 \mathrm{~d}$ the animals from both groups were killed by decapitation, selected organs were weighed and their AA content determined as previously described (Bessey, 1938; Hughes \& Hurley, 1969).

\section{RESULTS AND DISCUSSION}

The results are summarized in Table 1 . There was no significant difference in the relative weights of the spleen and liver between the two groups. The increase in the relative weight of the adrenals is presumably a stress effect of the food deprivation. The increase in brain relative weight is not unexpected and confirms previous studies that in weight loss induced by protein deficiency the absolute weight of the brain is less affected than that of other organs (Winick \& Noble, 1966; Alleyne, Halliday, Waterlow \& Nichols, 1969; Said, Hegsted \& Hayes, 1974).

Lowered tissue levels of essential nutrients are frequently an associative feature of protein undernutrition where there may be a concomitant reduction in the ingestion or absorption, or both of nutrients such as iron and folic acid. In the present experiment, however, all 
Table 1. Effect of dietary-induced weight loss in guinea-pigs on the weights and ascorbic acid concentrations of organs

(Values are means with standard error for eight animals.)

\begin{tabular}{|c|c|c|c|c|c|c|c|c|}
\hline \multirow{4}{*}{\multicolumn{2}{|c|}{$\begin{array}{l}\text { Initial body-weight } \\
(\mathrm{g}) \\
\text { Final body-weight } \\
\text { (g) } \\
\text { Change in mean } \\
\text { weight (g) }\end{array}$}} & \multicolumn{3}{|c|}{$\begin{array}{c}\text { Group A } \\
\text { (unrestricted food intake) }\end{array}$} & \multicolumn{4}{|c|}{$\begin{array}{c}\text { Group B } \dagger \\
\text { (restricted food intake) }\end{array}$} \\
\hline & & \multicolumn{3}{|c|}{$954 \pm 21$} & \multicolumn{4}{|c|}{$951 \pm 18$} \\
\hline & & \multicolumn{3}{|c|}{$991 \pm 30$} & \multicolumn{4}{|c|}{$705 \pm 22$} \\
\hline & & \multicolumn{3}{|c|}{+37} & \multicolumn{4}{|c|}{-246} \\
\hline & $\begin{array}{c}\text { Organ } \\
\text { weight } \\
\text { (g) }\end{array}$ & $\begin{array}{c}\text { Relative } \\
\text { organ } \\
\text { weight }\end{array}$ & $\begin{array}{c}\text { Ascorbic } \\
\text { acid } \\
(\mathrm{mg} / 100 \mathrm{~g})\end{array}$ & $\begin{array}{c}\text { Total } \\
\text { ascorbic } \\
\text { acid (mg) }\end{array}$ & $\begin{array}{c}\text { Organ } \\
\text { weight } \\
\text { (g) }\end{array}$ & $\begin{array}{l}\text { Relative } \\
\text { organ } \\
\text { weight }\end{array}$ & $\begin{array}{c}\text { Ascorbic } \\
\text { acid } \\
(\mathrm{mg} / 100 \mathrm{~g})\end{array}$ & $\begin{array}{c}\text { Total } \\
\text { ascorbic } \\
\text { acid (mg) }\end{array}$ \\
\hline Adrenals & $\begin{array}{r}0.433 \\
\pm 0.037\end{array}$ & $\begin{array}{r}0.044 \\
\pm 0.003\end{array}$ & $\begin{array}{c}38.5 \\
\pm 3.63\end{array}$ & $\begin{array}{r}0.165 \\
\pm 0.019\end{array}$ & $\begin{array}{r}0.471 \\
\pm 0.036\end{array}$ & $\begin{array}{l}0.068^{* * * *} \\
\pm 0.006\end{array}$ & $\begin{array}{c}23 \cdot 2 * * \\
\pm 3 \cdot 17\end{array}$ & $\begin{array}{l}0.104^{* *} \\
\pm 0.012\end{array}$ \\
\hline Spleen & $\begin{array}{r}0.934 \\
\pm 0.067\end{array}$ & $\begin{array}{r}0.094 \\
\pm 0.007\end{array}$ & $\begin{array}{r}13.9 \\
\pm 1.7\end{array}$ & $\begin{array}{r}0.128 \\
\pm 0.017\end{array}$ & $\begin{array}{r}0.754 \\
\pm 0.013\end{array}$ & $\begin{array}{r}0.107 \\
\pm 0.008\end{array}$ & $\begin{aligned} & 9.91^{*} \\
\pm & 0.41\end{aligned}$ & $\begin{array}{r}0.074 \\
\pm 0.005\end{array}$ \\
\hline Liver & $\begin{array}{c}35 \cdot 7 \\
\pm 2 \cdot 94\end{array}$ & $\begin{array}{r}3 \cdot 58 \\
\pm 0 \cdot 20\end{array}$ & $\begin{array}{r}5.07 \\
\pm 0.51\end{array}$ & $\begin{array}{r}1.89 \\
\pm 0.39\end{array}$ & $\begin{array}{l}27 \cdot 4 \\
\pm 2 \cdot 60\end{array}$ & $\begin{array}{r}3.90 \\
\pm 0.35\end{array}$ & $\begin{aligned} & 3 \cdot 19 * * * \\
\pm & 0 \cdot 22\end{aligned}$ & $\begin{array}{r}0.89 \\
\pm 0.15\end{array}$ \\
\hline Brain & $\begin{array}{r}4 \cdot 19 \\
\pm 0 \cdot 13\end{array}$ & $\begin{array}{c}0.42 \\
\pm 0.015\end{array}$ & $\begin{array}{r}11.02 \\
\pm 0.91\end{array}$ & $\begin{array}{r}0.46 \\
\pm 0.03\end{array}$ & $\begin{array}{r}4.19 \\
\pm 0.03\end{array}$ & $\begin{aligned} & 0.60 \\
\pm & 0.018\end{aligned}$ & $\begin{array}{r}9 \cdot 87 \\
\pm 0 \cdot 73\end{array}$ & $\begin{array}{c}0.42 \\
\pm 0.026\end{array}$ \\
\hline
\end{tabular}

Difference between means for groups $A$ and $B$ statistically significant: $* P<0.05,{ }^{* *} P<0.02$, *** $P<0.01$.

$\dagger$ For details see p. 299.

animals received, per unit of body-weight, identical amounts of ascorbic acid. Assuming no differences in the gastrointestinal absorption of AA between the two groups, the significant fall in the concentration of AA in the adrenals, spleen and liver would appear to support an earlier suggestion that the retention capacity of an organ towards AA is a function of the over-all metabolic activity of the organism (Williams \& Hughes, 1972). Previous studies have indicated that brain AA is relatively resistant to any over-all change in an organism's AA status (Ginter, Bobek \& Gerbelova, 1965; Hughes et al. 1971).

In practical terms the results carry certain implications for subjects of acute starvation and for those practising gross deprivation of food for reduction of body-weight. It would be of interest to determine whether leucocyte AA concentrations are reduced in persons undergoing 'starvation' treatment for obesity and also whether the retention of other nutrients by tissues is similarly affected by reductions in over-all nutrient intake.

J.E.W.D. was supported by a Beecham Products award.

\section{REFERENCES}

Alleyne, G. A. O., Halliday, D., Waterlow, J. C. \& Nichols, B. L. (1969). Br. J. Nutr. 23, 783.

Andrews, J. \& Brook, M. (1966). Lancet i, 1350.

Bessey, O. A. (1938). J. biol. Chem. 126, 771.

Brook, M. \& Grimshaw, J. J. (1968). Am. J. clin. Nutr. 21, 1254.

Ginter, E., Bobek, P. \& Gerbelova, M. (1965). Nutritio Dieta 7, 103.

Hughes, R. E. \& Hurley, R. J. (1969). Br. J. Nutr. 23, 211.

Hughes, R. E., Hurley, R. J. \& Jones, P. R. (1971). Br. J. Nutr. 26, 433.

Hughes, R. E. \& Jones, P. R. (1971), Br. J. Nutr. 25, 77.

Said, A. K., Hegsted, D. M. \& Hayes, K. C. (1974). Br. J. Nutr. 31, 47.

Williams, Rh. S. \& Hughes, R. E. (1972). Br. J. Nutr. 28, 167.

Winick, M. \& Noble, A. (1966). J. Nutr. 89, 300. 